\title{
DEFRAGMENTASI PENGAKTIFAN SKEMA MAHASISWA UNTUK MEMPERBAIKI TERJADINYA BERPIKIR PSEUDO DALAM MEMECAHKAN MASALAH MATEMATIS
}

\author{
${ }^{1}$ Kadek adi wibawa, ${ }^{2}$ Toto Nusantara, ${ }^{3}$ Subanji, ${ }^{4}$ I Nengah Parta \\ ${ }^{1}$ Universitas Mahasaraswati Denpasar, Jalan Kamboja No 11A, (0361) 240985 \\ 2,3,4 Universitas Negeri Malang, Jalan Semarang No 5, (0341) 551921 \\ Email: adiwibawa@unmas.ac.id
}

\begin{abstract}
Abstrak
Berpikir pseudo merupakan salah satu penyebab terjadinya kesalahan mahasiswa dalam memecahkan masalah matematis. Berpikir pseudo dibagi menjadi dua, yaitu berpikir pseudo salah dan berpikir pseudo benar. Dalam penelitian ini dikaji berpikir pseudo salah, yang mana mahasiswa salah dalam memecahkan masalah matematis, namun dapat melakukan perbaikan setelah melakukan berpikir reflektif melalui intervensi terbatas yang diberikan oleh peneliti. Proses perbaikan yang dilakukan oleh mahasiswa diamati melalui proses defragmentasi struktur berpikir yang terjadi. Hasil penelitian ini, mengungkap bahwa terjadi proses pengaktifan skema atau mahaisiswa mengaktifkan skema yang sudah dimiliki sebelumnya untuk memperbaiki kesalahan yang terjadi. Penelitian ini tergolong penelitian kualitatif dengan jenis deskriptif eksploratif. Peneliti menggunakan tiga subjek untuk menggambarkan proses defragmentasi pengaktifan skema yang terjadi. Eksplorasi dilakukan pada saat melakukan studi pendahuluan dan pada saat penelitian.
\end{abstract}

Kata Kunci: Berpikir pseudo-salah, intervensi terbatas, defragmentasi pengaktifan skema, dan memecahkan masalah matematis.

\begin{abstract}
Pseudo thinking is one of the causes of student error in solving mathematical problems. Pseudo thinking divided into two, that is false-pseudo thinking and pseudo-true thinking. In this study, pseudo-false thinking was considered, in which students were false in solving mathematical problems, but can make improvements after doing reflective thinking through limited intervention provided by researchers. The process of improvements made by students is observed through the process of defragmentation of thinking structures that occur. The results of this study, reveals that the process of activating the scheme or student activate a scheme that has been previously owned to correct errors that occured. This research is qualitative research with explorative descriptive type. Researchers used three subjects to describe the defragmentation process of scheme activation that occurred. Exploration was conducted during the preliminary study and at the time of the study.
\end{abstract}

Keywords: False-pseudo thinking, limited intervention, defragmentation of scheme activation, and solving of mathematical problems.

\section{PENDAHULUAN}

Dalam memecahkan masalah matematis, seringkali siswa mengalami kesulitan dan menghasilkan jawaban yang salah (Kiat, 2005; Yost, 2009; Dorko, 2011; dan Serhan, 2015). Masalah yang kompleks memerlukan variasi ide, strategi dan formulasi matematis yang digunakan. Hal itu mengakibatkan siswa harus berpikir keras agar bisa sampai pada jawaban yang benar dan sesuai dengan masalah yang dihadapi. Kesulitan seringkali menjadi hal pertama yang dialami dan dirasakan siswa, karena solusi dari masalah yang dihadapi tidak segera bisa diketahui dengan menggunakan prosedur-prosedur biasa. Situasi seperti ini telah dikaji oleh beberapa peneliti seperti Kiat (2005), Yost (2009), Zakaria, dkk. (2010), Dorko (2011), 
Wibawa (2013), Booth, dkk. (2014), Subanji (2015); Veloo, dkk. (2015), dan Serhan (2015). Penelitian yang telah dilakukan tersebut hanya mengidentifikasi adanya kesalahan yang terjadi melalui hasil kerja siswa. Penelitian-penelitian yang dilakukan belum sampai pada penemuan sumber kesalahan melalui pengungkapan proses berpikir siswa dalam memecahkan masalah matematis. Kiat (2005) mengungkapkan bahwa terdapat tiga jenis kesalahan dalam memecahkan masalah matematis, (1) kesalahan konseptual (conceptual error), (2) kesalahan prosedural (procedural error), dan (3) kesalahan teknis (technical error). Dalam hal ini Kiat (2005) belum menelusuri proses berpikir siswa yang mengalami kesalahan, oleh karena itu perlu dilakukan penelitian lebih lanjut terkait bagaimana proses berpikir siswa dalam memecahkan masalah matematis. Secara khusus, Serhan (2015) menyampaikan bahwa diperlukan adanya penelitian lanjutan untuk melakukan investigasi terhadap proses berpikir siswa ketika memecahkan masalah matematis.

Dalam menyelesaikan masalah, terdapat beberapa kemungkinan jawaban yang terjadi pada siswa. Untuk siswa yang memberikan jawaban benar dan mampu memberikan justifikasi, berarti jawabannya "benar sungguhan", hal ini sudah wajar. Sebaliknya, siswa yang menunjukkan jawaban benar, tetapi tidak mampu memberikan justifikasi terhadap jawabannya, maka kebenaran jawabannya hanya "kebenaran semu". Sedangkan siswa yang menunjukkan jawaban salah dan setelah refleksi tetap menghasilkan jawaban salah, berarti proses berpikir siswa tersebut memang "salah sungguhan". Perilaku lain yang mungkin adalah siswa memberikan jawaban salah, tetapi setelah melakukan refleksi mampu memperbaikinya sehingga menjadi jawaban benar. Menurut Vinner (1997) siswa tersebut berada pada posisi berpikir pseudo-salah. Selanjutnya dalam penelitian ini hanya dikaji proses berpikir siswa yang pseudo-salah. Hal ini didasari oleh pemikiran bahwa pseudo-salah akan merugikan siswa, karena sebenarnya siswa mampu menyelesaikan, tetapi karena proses refleksinya tidak maksimal, sehingga jawaban yang dihasilkan masih salah.

Subanji (2011:3) menyatakan bahwa siswa yang proses berpikirnya "pseudo" akan cenderung mengaitkan dengan masalah yang dianggapnya sama. Berpikir pseudo merupakan berpikir semu sehingga jawaban benar belum tentu dihasilkan dari suatu proses berpikir yang benar dan jawaban salah juga belum tentu dihasilkan dari suatu proses berpikir yang salah. Selanjutnya Vinner (1997) menjelaskan bahwa siswa terpaksa mempelajari topik-topik dan memecahkan masalah-masalah tertentu tapi tidak melakukan kontrol akan apa yang ia pikirkan. Oleh karena itu, berpikir pseudo bukanlah hasil dari proses berpikir siswa yang sebenarnya, melainkan berasal dari proses berpikir semu atau samar. 
Penelitian ini memfokuskan pengungkapan terjadinya kesalahan dalam memecahkan masalah matematis yang disebabkan oleh adanya fragmentasi struktur berpikir tipe pseudosalah. Fragmentasi struktur berpikir pseudo-salah disebut juga fragmentasi skema-non-aktif. Dalam hal ini, mahasiswa mampu menata struktur berpikirnya atau melakukan defragmentasi dengan mengaktifkan skema yang sudah dimilikinya.

\section{METODE PENELITIAN}

Data yang dikumpulkan dalam penelitian ini berupa kata-kata atau kalimat sehingga hasil penelitian ini berupa data deskriptif. Analisis data pada penelitian ini bersifat induktif karena kegiatan analisis datanya menggunakan fakta-fakta dari lapangan serta hasil think alouds untuk menemukan proses defragmentasi pengaktifan skema mahasiswa dalam memecahkan masalah matematis (aplikasi integral tentu pada volume benda putar). Menurut Creswell (2007), Bogdan \& Taylor (dalam Moleong, 2007), serta Yin (2011), penelitian semacam ini tergolong penelitian kualitatif.

Penelitian ini dilaksanakan di Program Studi Pendidikan Matematika FMIPA Universitas Negeri Malang pada mahasiswa semester genap angkatan tahun 2014 dan 2015 (Semester 4 dan 6). Peneliti memilih mahasiswa pendidikan matema-tika yang sudah mempelajari konsep integral sejak SMA dan menekuni kembali di perkuliahan (sesuai silabus materi aplikasian integral tentu pada volume benda putar diajarkan pada semester 2), diasumsikan memiliki struktur berpikir yang lebih lengkap dan mendalam sehingga proses eksplorasi yang dilakukan peneliti terkait dengan penelusuran fragmentasi struktur berpikir lebih tampak. Hal ini juga memudahkan peneliti untuk mengadaptasi berbagai cara penataan yang dilakukan ketika mahasiswa mengalami kesulitan atau salah dalam memecahkan masalah yang diberikan.

Sesuai dengan studi pendahuluan, dalam penelitian ini jawaban mahasiswa dikelompokkan menjadi 3 kategori: (1) Mahasiswa dengan kesalahan yang sangat esensial, dimana mahasiswa tidak menyadari adanya bangun yang "tidak beraturan" atau bangun ruang sisa yang melengkung, (2) Mahasiswa dengan kesalahan esensial, dimana mahasiswa menyadari adanya bangun yang "tidak beraturan" atau bangun ruang yang melengkung tapi tidak menggunakan integral tentu untuk menyelesaikannya, dan (3) mahasiswa dengan kesalahan cukup esensial, dimana mahasiswa menyadari adanya bangun yang tidak beraturan atau bangun ruang yang melengkung dan menggunakan integral tentu untuk menyelesaikannya

Defragmentasi Pengaktifan Skema Mahasiswa Untuk Memperbaiki Terjadinya Berpikir Pseudo dalam Memecahkan Masalah Matematis Wibawa, Nusantara, Subanji, Parta 
tapi jawaban yang diberikan salah. Peneliti melakukan penelitian pada 83 mahasiswa yang dibagi menajdi tiga kategori selanjutnya, subjek pada penelitian ini dipilih tiga untuk masingmasing kategori.

\section{HASIL DAN PEMBAHASAN}

Peneliti melakukan penelitian pada 3 kelas di Program Studi Pendidikan Matematika FMIPA Universitas Negeri Malang, yang masing-masing berjumlah 33 mahasiswa (semester 4) dan 52 mahasiswa (semester 6). Dari 85 mahasiswa yang diteliti, terdapat 2 jawaban $(2,35 \%)$ yang tidak diperhatikan karena tidak sesuai penelitian ini atau mahasiswa mengerjakan tidak sampai pada penemuan jawaban akhir. Hal ini mengakibatkan peneliti tidak mampu menemukan arah penyelesaian yang dilakukan. Dengan demikian, ada 83 (97,65\%) yang diperhatikan dan dianalisis lebih lanjut.

Dari 83 jawaban yang diperoleh, kemudian dibagi menjadi 3 kategori jawaban mahasiswa dan dianalisis setiap kesalahan yang terjadi. Persentase masing-masing kelompok yaitu: terdapat 63 mahasiswa $(75,90 \%)$ yang menjawab seperti yang dideskripsikan pada kategori 1, yang sebarannya 32 mahasiswa $(38,55 \%)$ dari semester 4, dan 31 mahasiswa $(37,35 \%)$ dari semester 6 . Untuk mahasiswa yang menjawab seperti yang dideskripsikan pada kategori 2, terdapat 17 mahasiswa $(37,35 \%)$ dan semua merupakan mahasiswa semester 6 . Pada kategori 3, terdapat 3 mahasiswa $(3,62 \%)$ yang menjawab seperti deskripsi dan 3 mahasiswa tersebut dari semester 6. Pada penelitian ini, dilakukan eksplorasi mendalam pada tiga subjek, yaitu subjek 1 (S1), subjek 2 (S2), dan subjek 3 (S3). Karakteristik S1 mewakili kategori tipe 1, S2 mewakili kategori tipe 2, dan S3 mewakili kategori tipe 3.

\section{Subjek 1 (S1)}

Ketika menghadapi masalah, S1 mampu memahami masalah dengan baik, bahwa terdapat bola yang dibor secara diametral dan diminta untuk menentukan volume sisanya. Pemahaman S1 dalam mengonstruksi kejadian bola yang dibor tidak utuh, sehingga mengakibatkan terjadinya kesalahan dalam menentukan "bangun ruang yang hilang" pada saat pengeboran dilakukan. Dalam hal ini, telah terjadi fragmentasi koneksi tanpa makna antara bola yang dibor, bangun ruang yang hilang, dan bangun ruang yang tersisa. S1 juga mengalami kesalahan dalam memberikan asumsi bahwa tinggi tabung sama dengan diameter bola. Hal ini terjadi, karena S1 meyakini bahwa bangun yang hilang dari kejadian bola yang dibor adalah tabung, padahal bangun yang hilang adalah tabung yang ada bagian melengkungnnya. 
S1 mampu melaksanakan rencana yang dibuat dalam menentukan volume manik-manik sebelum diukir (sebelum dibor) dengan benar, mulai dari menentukan rumus volume bola sampai pada perhitungan yang dilakukan. Kemudian S1 melanjutkan perhitungan dengan menentukan volume tabung. Adapun hasil pekerjaan S1 adalah sebagai berikut:

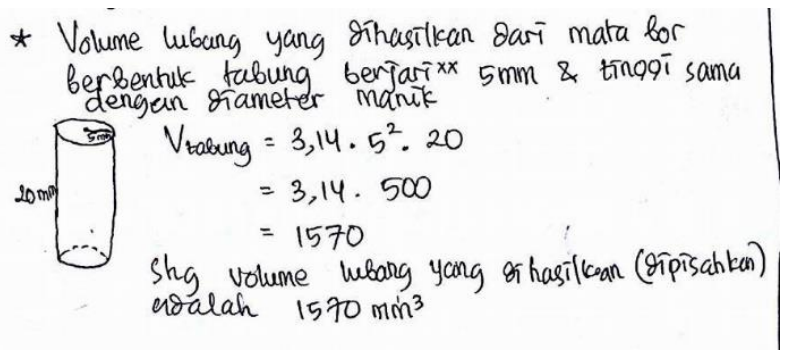

Gambar 1. Pekerjaan S1 dalam Menentukan Volume Tabung

Pernyataan S1 yang memperjelas pengerjaan yang dilakukan adalah sebagai berikut:

S1: Itu pastinya kan karena bentuknya manik-manik itu sama, dan pengeborannnya juga sama, jadi saya juga hanya menghitung volume satu lubangannya yang dihasilkan dari manik-manik itu yang berbentuk tabung, dengan cara Pi $r$ kuadrat $t$. $r$ nya diambil lima karena ini kan tabungnnya ini kan hasil dari pelubangan oleh mata bor yang jari-jarinya lima mili meter, terus kemudian dua puluh ini dapetnya dari diameternya manik-manik tadi, gitu.

S1 mampu mengingat rumus volume tabung dengan baik dan melakukan perhitungan dengan benar. Hanya saja jika ditelusuri lebih jauh, penentuan diameter bola sebagai tinggi tabung merupakan satu kesalahan, karena S1 hanya melihat sepintas gambar yang telah dibuat, yang seolah-olah menunjukkan bahwa diameter bola sama dengan tinggi tabung.

[71]P : Gimana caranya?

S1: Eee... karena ini kan tegak lurus dengan ini. Ini kesini itu, kan titik pusat kesana membentuk heputenusa. Terus begini jadinya begini. Misalkan ini disini adalah sepuluh dan disini kan setengahnya, jari-jari mata bor itu setengahnya jari-jari ini, berarti disini lima. Terus kemudian ini bisa dicari. (Indikasi terjadinya pengaktifan skema)

[73]P: Gimana caranya mencari.

[74] S1: Kalau misalkan digambar seperti ini, ini lima ini sepuluh, pakai teorema Pythagoras. a sama dengan akar sepuluh kuadrat dikurangi lima kuadrat, sama dengan akar seratus dikurangi tujuh puluh lima, sama dengan akar tujuh puluh lima, sama dengan lima akar tiga. (Indikasi terjadinya pengaktifan skema) 
Melalui wawancara tersebut, tampak bahwa peneliti mencoba mengarahkan S1 agar bisa mengaktivasi skema yang dimilikinya terikait penerapan teorema Pythagoras. Aktivasi skema berlangsung sangat cepat (dialog 72 dan 74). Ketika S1 sudah mampu menemukan komponen-komponen seperti: panjang sisi, sisi miring (hipotenusa), dan segitiga siku-siku pada gambar. Dalam hal ini, S1 mampu mengaktivasi skema yang dimilikinya tentang teorema Pythagoras setelah peneliti memberikan scaffolding. Aktivasi skema yang dilakukan S1, dapat membantunya untuk menentukan tinggi tabung dengan benar. Berikut adalah hasil kerja S1
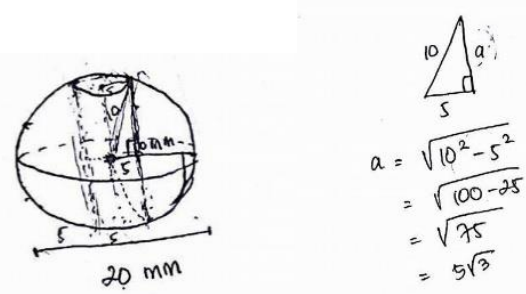

\section{Gambar 2. Pekerjaan S1 dalam Menentukan Tinggi Tabung Menggunakan Teorema Pythagoras}

\section{Subjek 2 (S2)}

S2 memiliki ciri khas dalam memecahkan masalah yang diberikan. S2 sudah menyadari sejak awal bahwa terdapat bangun ruang yang melengkung pada manik-manik yang dibor. Hanya saja, S2 tidak melakukan perhitungan untuk menentukan bangun ruang yang melengkung tersebut. S2 mengawali proses pemecahan masalah dengan memahami masalah dengan baik, kemudian melakukan perencanaan untuk menentukan volume sisa dua manikmanik yang dibor, dan melanjutkan pada proses melaksanakan rencana yang dibuat. Semua proses dilakukan dengan baik dan menemukan hasil yang menurut S2 sudah sesuai dengan apa yang ditanyakan. Akan tetapi peneliti dapat melihat satu kesalahan S2, yaitu kesalahan dalam menentukan tinggi tabung. Dalam hal ini, sebenarnya S2 sudah memiliki skema yang bisa digunakan untuk menentukan dengan benar tinggi tabung tersebut, hanya saja skema tersebut belum digunakan (belum diaktivasi). Sehingga peneliti menduga telah terjadi fragmentasi konstruksi pseudo pada memori S2. Hal yang bisa ditelusuri lebih dalam lagi adalah perhitungan bangun ruang yang melengkung pada manik-manik yang dibor. S2 menyimbolkannya sebagai $\mathrm{h}$.

S2 melaksanakan perencanaan yang dilakukan dengan menentukan volume bangun secara bergantian, Pertama yaitu menentukan volume tabung, kemudian volume bola, volume bangun ruang yang melengkung, volume sisa satu manik-manik yang dibor dan terakhir volume sisa dua manik-manik yang dibor. Berikut adalah pernyataan dari S2. 
[3] S2: Sehingga volumenya yaitu pi kali jari-jari kuadrat kali tinggi bor. Tinggi bornya ini sepanjang bola disini (menunjuk gambar soal). Pi nya tetap, jari-jari mata bor ini tadi lima mili meter. Sehingga lima kuadrat kali tinggi bornya ini sama aja dengan diameter dari bola sehingga sama dengan dua puluh mili meter, dari mana dua puluh ini? karena jari-jari bola adalah dua kali jari-jari mata bor, sehingga jari-jari bola disini adalah sepuluh mili meter, maka diameternya nya adalah dua puluh mili meter. Sehingga diameter bola disini adalah tinggi tabung disini sehingga diperoleh Pi kali dua puluh lima kali dua puluh sehingga hasilnya adalah lima ratus Pi.

S2 mampu memanggil memorinya dengan baik tentang rumus volume tabung, yaitu $V=\pi r^{2} t$. Akan tetapi terjadi kesalahan dalam menentukan tinggi tabung. S2 membuat alasan bahwa tinggi tabung sama dengan diameter bola. Adapun hasil kerja S2 dalam menentukan volume tabung adalah sebagai berikut:

$$
\begin{aligned}
V_{\text {mabe bor }} & =V_{\text {taparic }} \\
& =\pi \times r^{2} \times t \\
& =\pi \times S^{2} \times 20 \\
& =\pi \times 25 \times 20 \\
& =500 \pi
\end{aligned}
$$

\section{Gambar 3. Pekerjaan S2 dalam Menentukan Volume Mata Bor}

S2 mengalami kesulitan dalam menentukan fungsi dari volume yang akan dihitung. S2 memandang bahwa masalah yang dihadapi berbeda dengan seperti yang biasa S2 pelajari, yaitu fungsi dari volume yang dihitung sudah diketahui. Akan tetapi pernyataan S2 ini menunjukkan bahwa S2 menyadari pentingnya mengetahui fungsi atau persamaan terlebih dahulu sebelum menentukan bentuk integralnya. Peneliti menduga bahwa S2 sebenarnya sudah memiliki skema untuk menentukan fungsi atau persamaan yang dimaksud, akan tetapi skema tersebut belum diaktivasi oleh S2. Untuk itu berikut wawancara peneliti dan S2 dalam mengaktifkan skema yang dimilikinya.

[19]P : Kira-kira bagaimana cara menentukan fungsinya? (Memberikan scaffolding)

[20] S2: Cara menentukan fungsi ini, menurut pemahaman saya yaa, ini, kita kaitkan dengan trigonometri. Kemudian trigonometri kita bawa ke dalam bentuk fungsi kartesius. (indikasi terjadinya pengaktifan skema)

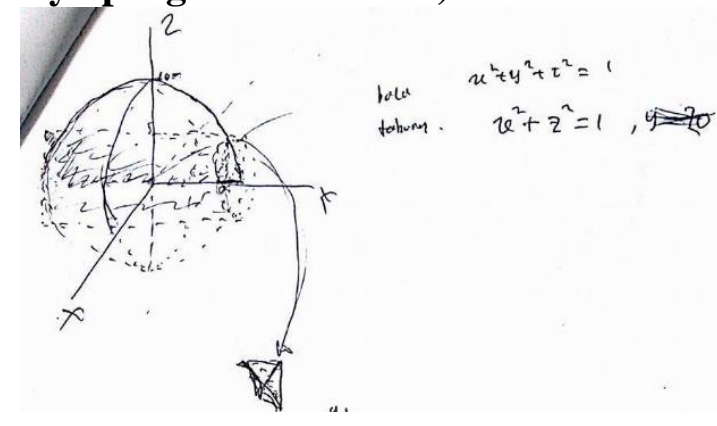


Gambar 4. Ilustrasi Bola yang Dibor pada Bidang Tiga Dimensi oleh S2

\section{Subjek 3 (S3)}

Pada saat menghadapi masalah yang diberikan, S3 mampu memahami masalah dengan baik dan menyadari bahwa terdapat bangun ruang yang salah satu permukaannya melengkung pada bagian bola yang dibor. S3 memikirkan bahwa bangun ruang yang salah satu permukaannya melengkung tersebut dapat diselesaikan dengan kalkulus (integral lipat tiga) tetapi S3 tidak mampu melanjutkan atau menerapkan integral lipat tiga yang dimaksud. S3 masuk dalam kategori 3, yaitu menyadari adanya bangun ruang yang salah satu permukaannya melengkung dan memikirkan integral untuk dapat membantunya menentukan volume bangun tersebut, namun terjadi kesulitan dalam menerapkannya. Dalam hal ini, skema berpikir S3 mengenai volume bangun ruang yang salah satu permukaannya melengkung atau bangun yang "tidak beraturan" dengan integral sudah terkoneksi namun tidak bermakna karena S3 tidak mampu melanjutkan apa yang harus dikerjakan. S3 mencoba untuk mengingat konsep integral yang bisa dimanfaatkan, akan tetapi S3 tidak mampu mengaitkan antar konsep-konsep tersebut.

S3 membagi bagian yang hilang dari bola menjadi 3 bagian, yaitu bagian A, B dan C. S3 mulai kesulitan dalam menentukan tinggi bangun yang dibuat untuk menentukan volumenya. S3 memfokuskan gambar pada bangun ruang yang salah satu permukaannya melengkung saja, dan menentukan panjang sisi yang mendatar, yaitu $5 \mathrm{~mm}$. S3 tidak menyadari melakukan kesalahan dalam menentukan panjang dari sisi yang sudah dibuat. Kemudian S3 berpikir tentang kalkulus karena bentuknya melengkung. Berikut pernyataan dari S3:

[5] S3: Selanjutnya (berpikir lama) untuk menghitung volume yang disini (bangun ruang yang melengkung) sebenarnya kita bisa menggunakan konsep yang ada di kalkulus, tapi kita kesulitan menentukan. eee... ini kan berupa lengkungan (menunjuk gambar 4.3.6). Karena ini lengkungan, kita harusnya bisa menentukan berapa ini persamaannya. Sampai disini saya kesulitan, karena saya belum bisa menentukan, jika menggunakan konsep kalkulus dia harus tahu berapa persamaannya. (fragmentasi konstruksi pseudo)

Peneliti memberikan scaffolding untuk mengarahkan S3 agar dapat mengaitkan permasalahan yang dihadapi dengan integral secara bermakna melalui pembuatan persamaan dari gambar yang dibuat. Sebelumnya Peneliti menduga bahwa sebenarnya S3 sudah memiliki skema mengenai diagram kartesius sebagai alat agar S3 mampu menentukan persamaan. Akan tetapi skema tersebut belum diaktivasi oleh S3. Adapun scaffolding yang dilakukan oleh peneliti adalah 
[12]P : Apa yang bisa dilakukan agar bisa mengaitkan dengan integral?

(Memberikan scaffolding)

[13] S3:(berpikir lama kemudian menggambar pada diagram kartesius). Yaa... ini persamaannya kalau digambar di kartesius. Iya, sepertinya ini. (Indikasi terjadinya pengaktifan skema)

\section{Defragmentasi Pengaktifan Skema}

Soal dengan tipe problem solving atau pemecahan masalah merupakan salah satu tipe soal yang memicu mahasiswa untuk mengaktifkan skema yang dimilikinya (Ron, dkk., 2006). Soal tipe problem solving memiliki tantangan yang lebih kompleks dibanding dengan soal-soal bersifat rutin atau prosedural. Tetapi sering kali yang terjadi bahwa mahasiswa tidak mampu mengaktifkan semua skema yang dimilikinya dalam memecahkan masalah yang dihadapi (Ron, dkk., 2006). Hal ini terjadi ketika mahasiswa mencoba untuk menentukan setengah dari tinggi tabung pada gambar yang sudah dibuat. Untuk menentukan setengah dari tinggi tabung tersebut, sebenarnya mahasiswa dapat menggunakan teorema Phytagoras, tetapi mahasiswa tidak bisa memunculkan skema tersebut (tidak menggunakan skema yang dimilikinya). Kondisi seperti ini disebut dengan fragmentasi stuktur berpikir pseudo atau tepatnya fragmentasi stuktur berpikir pseudo-salah.

Berdasakan fragmentasi stuktur berpikir pseudo yang terjadi, peneliti memberikan intervensi terbatas yang mengakibatkan mahasiswa melakukan defragmentasi pengaktifan skema. Berikut adalah ilustrasi defragementasi pengak-tifan skema yang dilakukan oleh mahasiswa dalam memecahkan masalah yang dihadapi.

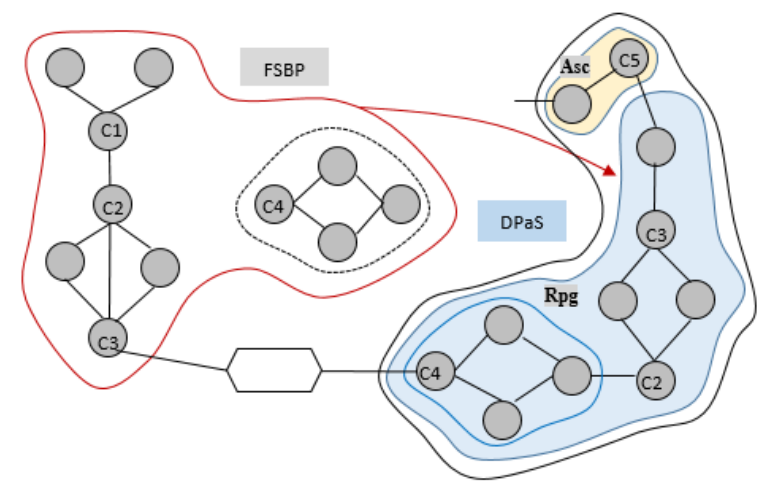

Gambar 5. Ilustrasi Defragmentasi Pengaktifan Skema oleh Mahasiswa pada Kasus yang Sederhana

\section{Keterangan:}

(C) = Konsep atau ide utama yang dikonstruksi oleh mahasiswa 
$O=$ Konsep atau ide pendukung (Bagian dari ide utama) yang dikonstruksi oleh mahasiswa

_ = Alur penyelesaian masalah yang menghubungkan skema (penghubung antar skema yang dikonstruksi)

$=$ Penghubung antar skema yang tidak dikonstruksi secara bermakna (low connected)

$\longrightarrow=$ Proses defragmentasi yang terjadi (awalnya mahasiswa mengalami fragmentasi struktur berpikir kemudian mampu memperbaiki/menata kembali)

$\Xi$ = Struktur berpikir subjek yang menunjukkan adanya fragmentasi

$\zeta$ = Struktur berpikir subjek yang menunjukkan defragmentasi berdasarkan kerangka CRA

$=$ Struktur berpikir subjek yang menunjukkan proses repairing (warna biru muda)

$=$ Struktur berpikir subjek yang menunjukkan proses ascertaining (warna orange muda)

FSBP $=$ Fragmentasi struktur berpikir pseudo

$\mathrm{DPaS}=$ Defragmentasi pengaktifan skema

$\square=$ Intervensi terbatas

$\therefore=$ = Skema yang belum diaktivasi (belum dikonstruksi)

$\Xi$ = Skema yang sudah diaktivasi (sudah dikonstruksi)

Gambar 5. merupakan interpretasi peneliti terhadap defragmentasi pengaktifan skema yang terjadi ketika mahasiswa mencoba untuk mengatasi kesulitannya dalam menentukan fungsi atau persamaan agar dapat mengaitkan antara volume bangun yang melengkung dengan integral. C1 merupakan ide tentang bangun ruang yang salah satu permukaannya melengkung yang ingin ditentukan volumenya oleh mahasiswa. Mahasiswa berpikir bahwa untuk menghitungnya dapat menggunakan integral (C3), dan untuk menggunakan konsep integral mahasiswa mengatakan bahwa harus mengetahui fungsi atau persamaannya terlebih dahulu (C2). Pada tahap ini, mahasiswa tidak dapat menemukan ide untuk melanjutkan ke tahap berikutnya.

Salah satu cara untuk membuat representasi fungsi adalah melalui diagram kartesius. Mahasiswa pada Gambar 5 menunjukkan bahwa sebenarnya mahasiswa sudah memiliki skema tentang diagram kartesius tersebut (C4), tetapi skema tersebut belum diaktivasi. Oleh karena itu, peneliti melakukan intervensi terbatas berupa scaffolding, dengan menanyakan “apa yang bisa dilakukan agar bisa menggunakan integral?”. Mahasiswa dengan cepat langsung mengatakan bahwa gambarnya dapat dibuat pada diagram kartesius. Melalui diagram 
kartesius mahasiswa dapat menentukan fungsi dan persamaan serta bangun ruang yang melengkung tersebut. Mahasiswa memberikan argumentasi bahwa dengan membuat gambar pada diagram kartesius bisa memudahkannya membuat grafik dan menentukan persamaan (A5).

Ilustrasi yang lain mengenai defragmentasi pengaktifan skema terjadi pada kasus yang berbeda. Mahasiswa mencoba untuk menentukan tinggi setengah tabung. Awalnya mahasiswa menyamakan tinggi setengah tabung dengan jari-jari bola, tetapi setelah dipertanyakan melalui penciptaan disequilibrasi, mahasiswa menyadari kesalahannya. Mahasiswa mencoba untuk mengerjakan kembali dengan cara yang berbeda, tetapi mengalami kesulitan. Dalam hal ini, sebenarnya maha-siswa sudah memiliki skema berpikir tentang teorema Phytagoras yang dapat digunakan untuk memecahkan masalahnya, tetapi skema tersebut belum diaktivasi oleh mahasiswa tersebut. Berikut adalah ilustrasi struktur berpikir mahasiswa, bagaimana mahasiswa melakukan defragmentasi pengaktifan skema.

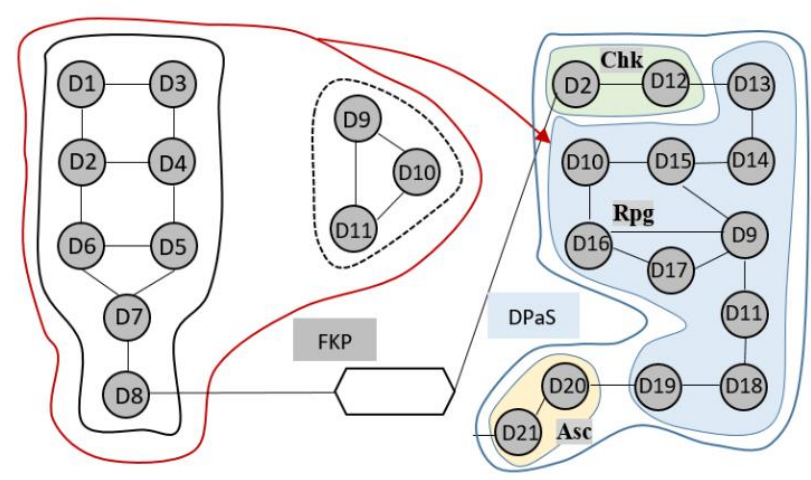

Gambar 6. Ilustrasi Defragmentasi Pengaktifan Skema oleh Mahasiswa pada Kasus yang Kompleks

Keterangan mengikuti gambar $\mathbf{5}$.

Mahasiswa awalnya mengonstruksi masalah tentang bola yang dibor (D1). Kemudian mahasiswa menentukan hasil pengeboran, yaitu bola (D2) dan bangun yang dibuang atau hilang (D3). Mahasiswa memahami bahwa bangun yang dibuang tersebut merupakan tabung (D4). Kemudian mahasiswa menentukan tinggi tabung (D5) agar dapat menghitung volume tabung sebagai bagian dari bangun yang dibuang. Mahasiswa memperhatikan diameter bola (D6) dan memahami bahwa tinggi tabung sama dengan diameter bola (D7). Mahasiswa kemudian menentukan tinggi tabung sama dengan $20 \mathrm{~mm}$. Dalam hal ini, jawaban mahasiswa salah karena tinggi tabung tidak sama dengan diamater bola. Tabung memiliki tinggi kurang dari diameter bola. Kesalahan yang terjadi karena mahasiswa mengasumsikan bahwa bagian 
yang dibuang adalah tabung. Hal ini mengakibatkan mahasiswa berpandangan bahwa tinggi tabung seolah-olah sama dengan diameter bola.

Apabila ditinjau dari pola struktur berpikir mahasiswa, sebanarnya mahasiswa sudah memiliki skema tentang teorema Phytagoras yang dapat dimanfaatkan untuk menentukan tinggi tabung tersebut. Tetapi skema tersebut belum diaktivasi oleh mahasiswa. Mahasiswa memerlukan beberapa ide agar bisa mengaktifkan skema yang dimilikinya. Ron, dkk. (2006) membuat formulasi pengaktifan skema yang terjadi pada memori jangka pendek. Dalam formulasi tersebut, terdapat tiga hal yang menjadi dasar suatu skema dapat diaktivasi. Pertama, aktivasi skema ditentukan oleh kondisi awal masalah yang dihadapi. Kedua, bobot atau kualitas perhatian yang diberikan pada masalah yang dihadapi. Ketiga, kekuatan hubungan dari tiaptiap elemen yang akan diaktivasi. .

Peneliti memberikan intervensi terbatas berupa penciptaan disequilibrasi dan pemberian scaffolding pada mahasiswa agar bisa mengaktifkan skema yang dimilikinya. Melalui penciptaan disequilibrasi, mahasiswa memperhatikan gambar yang dibuat (D2) dan memberikan atensi pada tinggi tabung yang sudah ditentukan. Mahasiswa memandang lingkaran sebagai irisan bola (D12). Kemudian mahasiswa memaparkan pengertian lingkaran, yaitu himpunan titik-titik yang berjarak sama terhadap titik pusat (D13). Jarak yang sama yang dimaksud adalah jari-jari lingkaran. Mahasiswa menentukan jari-jari lingkaran $10 \mathrm{~mm}$ (D14). Mahasiswa memfokuskan diri untuk menentukan setengah tinggi tabung yang ada pada kuadran I. Mahasiswa menentukan jarak titik pusat lingkaran ke perpotongan lingkaran dan tabung (dibuat persegi panjang dalam dua dimensi) $10 \mathrm{~mm}$ (D15). Mahasiswa menyadari bahwa terdapat segitiga siku-siku (D9). Mahasiswa menentukan sisi miring dari segitiga sikusiku tersebut (D10), yaitu 5 mm (D17). Panjang sisi miring tersebut ditentukan melalui jarak perpotongan lingkaran dan tabung ke sumbu X yang sama dengan jari-jari tabung (D16). Mahasiswa kemudian menerapkan teorema Phytagoras (D11) dan memperoleh panjang setengah tinggi tabung sama dengan $5 \sqrt{3}$ (D18) dan tinggi tabung sama dengan $10 \sqrt{3}$ (D19). Dalam hal ini, mahasiswa sudah menemukan jawaban yang benar dalam menentukan tinggi tabung. Mahasiswa memastikan jawabannya bahwa pada segitiga siku-siku dapat diterapkan teorema Phytagoras (D20) dan setengah tinggi tabung merupakan bagian dari salah satu sisi segitiga siku-siku (D21). Di tinjau dari pola struktur berpikir, mahasiswa sudah melakukan defragmentasi pengaktifan skema. Mahasiswa mangaktifkan skema yang dimilikinya terkait dengan penerapan teorema Phytagoras pada segitiga siku-siku untuk menentukan tinggi tabung. 


\section{SIMPULAN DAN SARAN}

Defragmentasi pengaktifan skema yang dilakukan oleh mahasiswa diawali dengan adanya fragmentasi konstruksi pseudo atau fragmentasi konstruksi pseudo-salah. Fragmentasi konstruksi pseudo-salah tampak ketika mahasiswa mengalami kesalahan dalam memecahkan masalah matematis. Ditinjau dari pola struktur berpikir mahasiswa secara utuh, kesalahan yang terjadi sebenarnya dapat diatasi oleh mahasiswa, karena mahasiswa sudah memiliki skema yang dapat digunakan untuk memecahkan masalahnya, hanya saja skema tersebut belum diaktivasi. Peneliti memberikan intervensi terbatas yang tujuannya agar mahasiswa mampu menyadari kesalahan yang terjadi dan memperbaiki kesalahannya sendiri. Mahasiswa melakukan checking dengan memikirkan kembali ide-ide yang sudah dikonstruksi. Mahasiswa memunculkan kesadarannya bahwa diperlukan ide yang bisa diaktivasi agar dapat memperbaiki kesalahan yang terjadi. Mahasiswa melakukan repairing dengan respon yang cepat "oh.. ternyata bisa menggunakan cara/strategi ini...". Mahasiswa melakukan penstrukturan ulang dengan menambahkan skema baru yang sudah diaktivasi. Mahasiswa kemudian melakukan ascertaining dengan memastikan bahwa skema yang diaktivasi sudah sesuai dengan masalah yang dihadapi.

Dalam penelitian ini karakteristik subjek belum dipertimbangkan untuk mengungkap adanya fragmentasi dan defragmentasi struktur berpikir. Oleh karena itu, bagi yang berminat dengan kajian tersebut bisa diteliti lebih lanjut dengan mempertimbangkan karakteristik mahasiswa yang dijadikan sebagai subjek. Dalam hal ini, karakteristik yang dimaksud adalah gaya belajar, gaya kognitif, dan karakteristik kepribadian mahasiswa.

\section{DAFTAR PUSTAKA}

Anghileri, J. 2006. Scaffolding Practices that Enhance Mathematics Learning. Journal of Mathematics Teacher Education, 9(1), 33-52.

Baggesen, M. 2017. How to Defrag Your Windows Computer. https://www.lifewire.com/howto-defrag-your-computer-3506876 [Diakses Agustus 2017].

Booth, J.L., Barbieri, C., Eyer, F., \& Pare-Blagoev, E.J. 2014. Persistent and Pernicious Errors

in Algebraic Problem Solving. Journal of Problem Solving, 7, 10-23. http://dx.doi.org/10.7771/1932-6246.1161.

Creswell, J.W. 2007. Qualitative Inquiry and Research Design. Choosing among Five Approaches (2nd ed.). Thousand Osks, CA: Sage. 
Dorko, A. 2011. Calculus Student' Understanding of Area and Volume in Non-Calculus Context. Unpublished masters thesis, University of Maine at Orono.

Kiat, S.E. 2005. Analysis of Student' Difficulties in Solving Integration Problems. The Mathematics Educator, 9(1), 39-59.

Moleong, L.J. 2007. Metodelogi Penelitian Kualitatif. Bandung: PT Remaja Rosdakarya Offset.

Ron, S., dkk. 2006. Cognition and Multi-Agent Interaction: From Cognitive Modeling to Social Simulation. Cambridge University Press: New York.

Serhan, D. 2015. Students' Understanding of the Definite Integral Consept. International Journal of Research in Education and Science (IJRES), 1(1), 84-88.

Subanji. 2011. Teori Berpikir Pseudo Penalaran Kovariasional. Malang: Universitas Negeri Malang (UM Press).

Vinner, S.1997. The Pseudo-Conceptual and the Pseudo-Analytical Thought Processes in Mathematics Learning. Educational Studies in Mathematics 34, pp. 97-129.

Veloo, A., Krishnasamy, H.N., \& Abdullah, W.S.W. 2015. Types of Student Errors in Mathematical Symbols, Graphs, and Problem-Solving. Asian Social Science, 11(15), 324-334. Canadian Center of Science and Education.

Wibawa, K.A., Subanji, Chandra, T.D. 2013. Defragmenting Berpikir Pseudo dalam Memecahkan Masalah Limit Fungsi. Makalah disampaikan dalam Seminar Nasional Exchange of Experiences Teachers Quality Improvement Program (TEQIP) di Universitas Negeri Malang. 9 November 2013.

Yin, R.K. 2011. Qualitative Research from Start to Finish. New York: The Guilford Press.

Yost, D. 2009. Integration: Reversing Traditional Pedagogy. Australian Senior Mathematics Journal, 22, 37-40.

Zakaria, E., Ibrahim, \& Maat, S.M. 2010. Analysis of Students' Error in Learning of Quadratic Equations. International Education Studies, 3 (3), 105-110. 